Article

\title{
Origin of Knickpoints in an Alpine Context Subject to Different Perturbing Factors, Stura Valley, Maritime Alps (North-Western Italy)
}

\author{
Monica Marrucci ${ }^{1}$, Gerold Zeilinger ${ }^{2}$, Adriano Ribolini ${ }^{1} * * \mathbb{C}$ and Wolfgang Schwanghart ${ }^{2}$ \\ 1 Department of Earth Sciences, University of Pisa, 56126 Pisa, Italy; monica.marrucci@gmail.com \\ 2 Institute for Earth and Environmental Sciences, University of Potsdam, 14476 Potsdam, Germany; \\ zeilinger@geo.uni-potsdam (G.Z.); schwangh@uni-potsdam.de (W.S.) \\ * Correspondence: adriano.ribolini@unipi.it or ribolini@dst.unipi.it; Tel.: +39-050-2215769
}

Received: 31 August 2018; Accepted: 15 November 2018; Published: 28 November 2018

\begin{abstract}
Natural catchments are likely to show the existence of knickpoints in their river networks. The origin and genesis of the knickpoints can be manifold, considering that the present morphology is the result of the interactions of different factors such as tectonic movements, quaternary glaciations, river captures, variable lithology, and base-level changes. We analyzed the longitudinal profiles of the river channels in the Stura di Demonte Valley (Maritime Alps) to identify the knickpoints of such an alpine setting and to characterize their origins. The distribution and the geometry of stream profiles were used to identify the possible causes of the changes in stream gradients and to define zones with genetically linked knickpoints. Knickpoints are key geomorphological features for reconstructing the evolution of fluvial dissected basins, when the different perturbing factors affecting the ideally graded fluvial system have been detected. This study shows that even in a regionally small area, perturbations of river profiles are caused by multiple factors. Thus, attributing (automatically)-extracted knickpoints solely to one factor, can potentially lead to incomplete interpretations of catchment evolution.
\end{abstract}

Keywords: knickpoint; river longitudinal profile; Maritime Alps

\section{Introduction}

Drainage networks have the potential to record the effects of surface processes influenced by tectonic growth of relief, lithology, climate and erosion [1-5]. The longitudinal river profiles of both alluvial and bedrock channels develop a shape that is optimized for sediment transport and bedrock erosion [6-9]. A stream with an adjusted gradient is defined as a graded stream. The longitudinal profile of an ideal graded stream shows a concave-up shape with a steeper slope upstream giving way to a gentle slope in the downstream direction. New environmental conditions (climatic change, tectonic uplift, base level drop, etc.) may perturb the graded stream and cause a knickpoint in the longitudinal river profile, i.e., a steeper reach of the stream with respect to the adjoining up- and downstream reaches. One knickpoint then divides the stream profiles into two segments with different gradients. Knickpoints mostly indicate the position of the upstream-moving erosional front separating relict landscapes that still record the former base-level from a rejuvenated setting, currently adapting to a newly established base-level. In contrast, some knickpoints show a very limited upstream movement in time so to be considered stationary (e.g., structurally- or lithologically-induced knickpoints).

The different origins of knickpoints can be related to factors such as tectonics, lithology, base-level falls, glacial activity, increased or decreased river discharge by confluences or landslide dams [1,10-13]. These factors are not exclusive and can superpose their effects, so as to result in a complex interpretation of the genesis of the knickpoints. Several authors [1,4,14-16] have found multiple causality within the 
same drainage system, pointing out the complexity of this issue. Furthermore, a distinction should be made between knickpoints caused by regional factors and those determined by local perturbation agents. While the former usually inherit information on tectonic uplift or climatic changes, the latter may be related to local fluvial captures, lithological control, and landslides. The detection, dynamics, and influence of the knickpoints in landscape evolution have been investigated in recent studies [17-21], which emphasize that mono-causal knickpoints in river networks are generally well understood, but that in the majority of natural catchments multi-causal knickzone systems are possible.

The aim of this study is to identify the prevailing processes active in generating knickpoints in such a natural, alpine basin, which is affected by tectonic uplift and Pleistocene glaciation and is sensitive to base-level changes at the transition between mountain front and foreland. We chose the Stura River basin (Figure 1) because its morphology was shaped by tectonics, Quaternary glacial phases, variable lithology, and base-level falls created by river captures. Insights into drainage system and related landforms were provided by recent geomorphological studies on different sectors of the Stura Valley [22-26], and of the Italian and French sides of the Argentera Massif [27-33]. However, a robust basin-scale analysis of the existence and distribution of knickpoints, together with studies on their genesis, is still lacking.

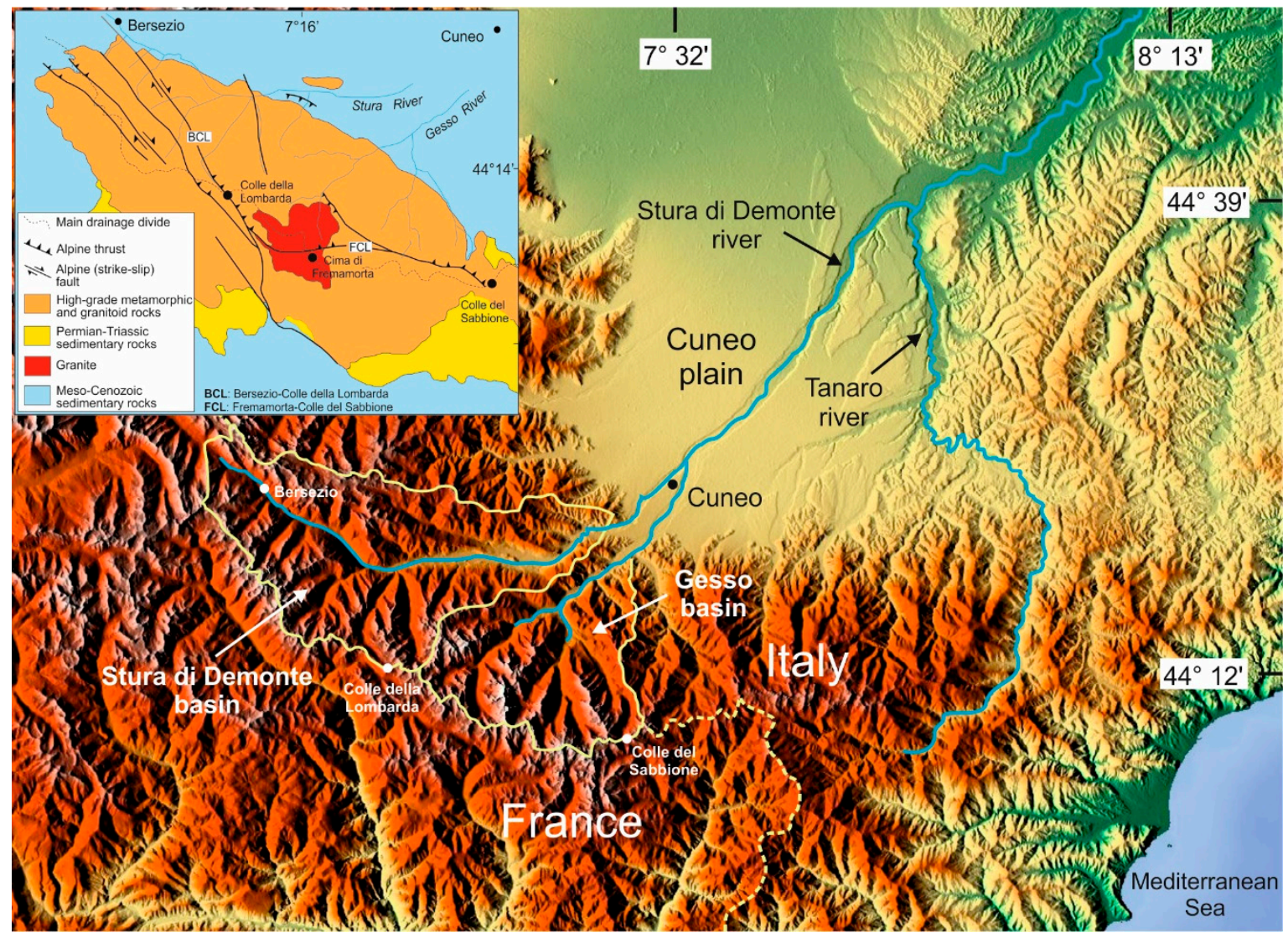

Figure 1. Location of the Stura basin in the Maritime Alps (southern Western Alps). A simplified bedrock geology and the main tectonic structures are reported in the inset (re-drawn and summarized after [30]).

The knickpoints were identified both on the main channel of the Stura basin and of its tributaries, and their geometry and distribution were examined to test potential relationships with lithology, morphology, and known tectonic structures. 


\section{Regional Setting}

The Stura basin is located in the Maritime Alps, which are part of the southern Western Alps (Figure 1). It has an extension of $590 \mathrm{~km}^{2}$ and its altitude ranges from about $3000 \mathrm{~m}$ at the watershed divide to $580 \mathrm{~m}$ a.s.l., where the Stura di Demonte flows into the Cuneo Plain. The Stura di Demonte river originates from Colle della Maddalena (1996 m a.s.l) and runs for a hundred kilometers up to its confluence with the Tanaro river. From the French border to the village of Pianche, Stura di Demonte flows from NW to SE parallel to the major tectonic boundary and to the long axis of the Argentera massif (NW-SE), showing the characteristics of an intra-orogenic drainage system [29]. Downstream of the Pianche village, the river flows perpendicular to some important geological structures, which expose both metamorphic rocks of the Argentera Massif and its sedimentary cover (Figures 1 and 2).

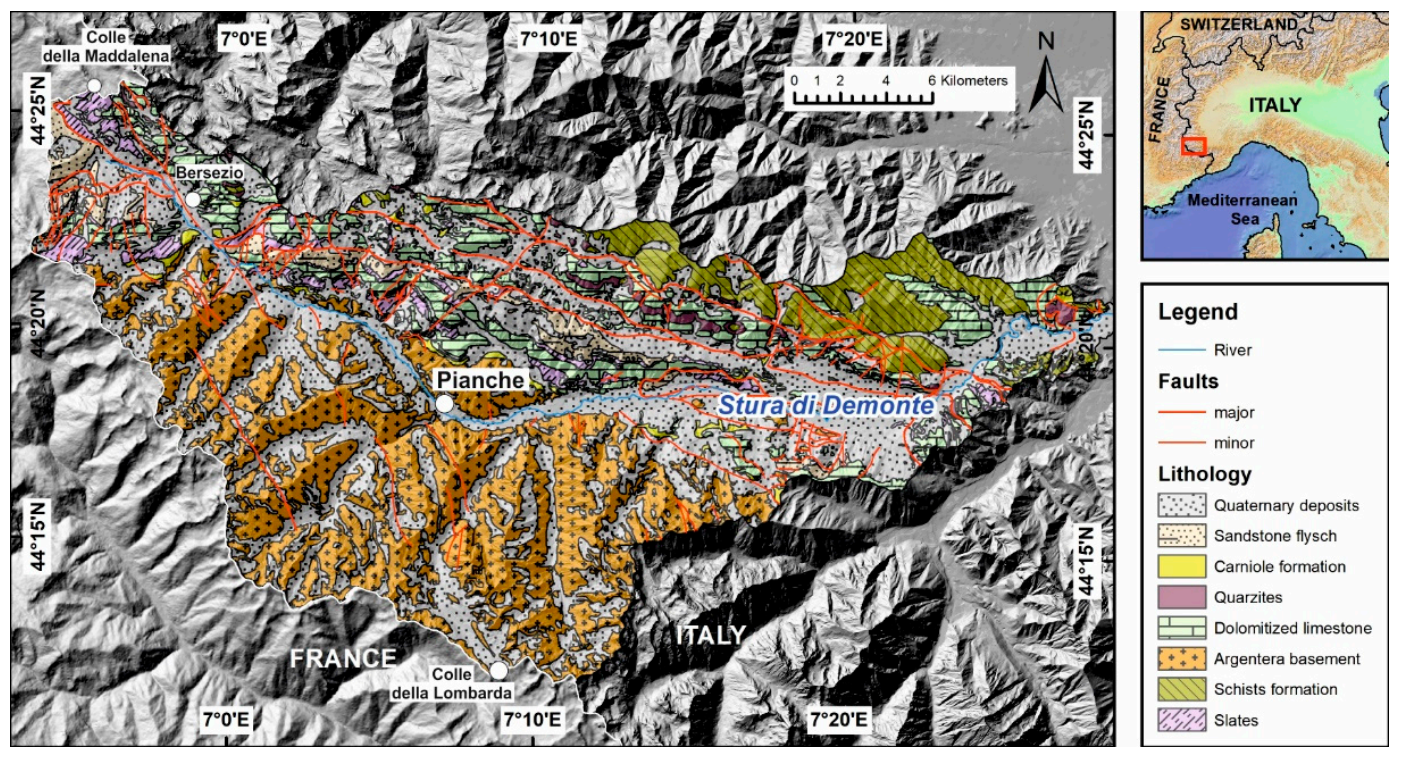

Figure 2. Location of the Stura catchment in the Maritime Alps with Argentera basement outcropping in the SW and dominated in the N by (Meta-) sedimentary rocks. (Geology: redrawn and summarized after [34]; DEM for hillshade in Italy from TINITALY/01, DEM for hillshade in France from NASA JPL., 2013; Inset Map produced using Copernicus data and information funded by the European Union-EU-DEM layers).

The southern flank of the Stura Valley is made up of high-grade metamorphic and granitoid rocks $[34,35]$ of the Argentera Massif. The northern side is formed by the Permian autochthonous sedimentary cover and by Mesozoic and Cenozoic series, which were emplaced onto the basement along Triassic evaporites. While the Permian sedimentary cover is made up of quarzites and quarzitic sandstone, the Mesozoic and Cenozoic sequences are mainly composed of calcareo-dolomitic formations and sandstone flysch (Figure 2).

The main tectonic lineaments in the basement are associated with the NW trending Bersezio-Colle della Lombarda fault system and the WNW trending Fremamorta-Colle del Sabbione Line in the Gesso basin [31,36,37] (Figures 1 and 2). Both correspond to late Variscan shear zones reactivated during the Alpine collision [30,38]. While the Bersezio-Colle della Lombarda fault system shows a right-lateral component [39], the Fremamorta-Colle del Sabbione Line is dominated by reverse shearing [30]. During Upper Miocene-Pliocene an important thrusting occurred along the Fremamorta-Colle del Sabbione Line, leading the NE portion of the Argentera to be thrust towards the SW onto the rest of the basement. The dextral Bersezio-Colle della Lombarda fault system acted as a right lateral ramp (transpressive transcurrent fault) during this time [37]. All these tectonic structures accommodated the NW-SE crustal shortening, building a pop-up structure [39,40]. 
On the basis of apatite fission track analysis, Bigot-Cormier et al. [41] argued for differential vertical motions of blocks within the Argentera Massif. Musumeci et al. [29] suggested, on the basis of geomorphic and structural data, that Pliocene to recent active tectonics had led to a higher degree of uplift in the central-southern section with respect to the other parts of the Argentera Massif.

The sedimentary cover is mainly deformed along WNW-ESE trending thrust systems with a SW vergence [34].

The present day tectonic setting is thus mainly related to the exhumation of the Argentera Massif, which started between Late Oligocene and early Miocene, and increased at 3.5 Ma to rates of $0.8-1 \mathrm{~mm} /$ year [41-43].

Recent seismic and GPS data confirmed that the studied part of the Maritime Alps is under transpressive tectonic stress, with N-S to NE-SW directed crustal shortening of 2-4 mm/year [44-46]. The tectonic activity in the south-western part of the Cuneo Plain, starting in the Middle-Upper Pleistocene and ongoing until today, must have influenced the evolution of the Stura basin, at least in the lower valley. This area of the Cuneo Plain underwent folding and faulting, which modulated the deviation of the Tanaro river [47-49], i.e., the receiving stream of the Stura di Demonte. This led to backward incision in the entire Tanaro hydrographic network, recorded also in the lower Stura Valley by several levels of fluvial terraces [26].

The present morphology of the catchments draining the Italian side of the Maritime Alps is mainly related to processes associated with glacial and fluvial activities. The Last Glacial Maximum (LGM) and the Late Glacial periods left the most evident landforms: U-shaped valleys, glacial deposits, moraines, glacial cirques, and scarps [22-25,50-55]. A suite of frontal moraines indicates the glacier retreat from the lower main valley at maximum expansion to the uppermost cirques of the lateral tributaries at today's position.

The main processes of sediment transport are currently related to the fluvial system with a minor contribution of detrital supply from steep valley flanks [56]. All these processes superimpose the locally eroded and reworked glacial landforms.

\section{Methods}

The drainage network was digitized on 1:10,000 scale topographic maps and served as a quality reference for the DEM extracted river network. The two river datasets overlap and show no significant offset $(>50 \mathrm{~m}$ ) The longitudinal profiles of the main channel and of its direct tributaries had been extracted from a $10 \mathrm{~m}$ resolution DEM [57,58]. They correspond mainly to rivers of the Strahler Order equal or greater than three with an average upstream area of approx. 160,000 $\mathrm{m}^{2}$ (a square of 400 by $400 \mathrm{~m}$ ). The first- and second-order channels have been excluded since they have minor drainage areas (approx. $10000 \mathrm{~m}^{2}$ to $100,000 \mathrm{~m}^{2}$ ) and are typically ephemeral or intermittent streamflows. Additionally to the channel length profile, the variation of slope along the channel (expressed as rise per $\mathrm{m}$ ) was calculated and plotted in order to improve the identification of the knickpoints. The variation of slope along the channels was calculated by dividing the profiles into $150-\mathrm{m}$ segments, extracting the difference between the elevations of the two extreme points (150 m downstream and $150 \mathrm{~m}$ upstream of each point), and dividing it by the segment length. Longer segments reduce the noise in the slope diagram, but still depict the knickpoints with their peaks.

The spatial distribution of knickpoints was intersected with lithological features, structures, inherited morphologies, and terraces. The structural features are the main faults reported in geological maps $[34,35,59]$ and the shear zones and lineament sets are associated with fault rocks ([30] and reference therein). The lithologies in the geological map [34] have been grouped on the basis of similar rock strength and hardness, assuming that they are similarly affected by erosion. The weakest units are the unconsolidated quaternary deposits, followed by low to medium strength Slates, Schist formations, and Argillites, and high strength Dolomitized limestones, Sandstone flysches, and Carniole formations. The very high-strength class is formed by the Basement (metamorphic and granitoid rocks) and by Quarzites. Grouping is not based on strength values obtained from laboratory tests for strength, but 
a qualitative measure of field tests with a hammer, inspired by the Schmidt Hammer test [60], was applied. The potential relationship between knickpoints and base-level falls, like different levels of fluvial terraces is given in the lower part of the Stura basin. Therefore, the terraces were delineated on the basis of aerial photographs, field verifications, and digital elevation models. The longitudinal profiles of the tributaries flowing into the Stura River across terrace levels were analyzed to quantify knickpoint retreated. The morphologies inherited from the past glaciations were identified and characterized at hanging valleys in tributaries near their confluence with the trunk streams, by using digital elevation models, aerial photographic interpretation, and field reconnaissance. The correlation between these glacial landforms and the knickpoints located in the terminal part of several tributaries of the Stura di Demonte river was verified in the field. The locations of all identified knickpoints are superimposed on the map containing the lithologies, structures, and terraces. Knickpoints that are caused by one of the above-mentioned features had been classified accordingly. However, several knickpoints could not be attributed to a single cause and are classified as "undefined".

Whether knickpoints relate to a common base level fall at the valley outlet or further downstream can be tested using $\mathrm{X}-(\mathrm{X})$-analysis. $\mathrm{X}$-analysis is based on the transformation of the along-river horizontal distance measured from the outlet of a drainage basin. The transformation is predicated on the stream power incision model [61], and uses upslope area to linearize the concave upward profile for a chosen value of the concavity index, or $\mathrm{m} / \mathrm{n}$ ( $\mathrm{m}$ and $\mathrm{n}$ constants in the stream power model) [62]. Following the stream power incision model, knickpoints should migrate at velocities proportional to upstream area to the power of $\mathrm{m}$. Thus, if knickpoints relate to a common base level fall at the outlet or further downstream, their locations should cluster on narrow ranges of X [62]. We calculated the X-transform using TopoToolbox [63] using a $\mathrm{m} / \mathrm{n}$ ratio of 0.45 . We calculated frequency distributions of the entire stream network and those of the individual knickpoint classes using a Gaussian kernel with a bandwidth of $250 \mathrm{~m}$. Changing the ratio did affect X-values, but had a minor influence on the frequency distribution of knickpoint $\mathrm{X}$-values.

\section{Results}

Both the main channel and the tributaries of the Stura di Demonte hydrographic network show abrupt changes in the gradient of their longitudinal profiles representing single knickpoints or wider knickzones (i.e., an area of slope discontinuity similar to a knickpoint, but occurring over a greater length of a channel or of a series of smaller knickpoints). In detail, we recognized more than 90 knickpoints presenting different amplitudes, slopes and positions within the Stura drainage system. Some are relatively small steps of just a few meters, others are outright falls or convex segments (Figure 3).

For half of these knickpoints the factor responsible for their origin was identified, defined in zones within the basin, and grouped in four different categories that are described below. The other half of the knickpoints could not be unambiguously interpreted, probably because of the multiple causality of their genesis (superimposed tectonic uplift, erosional contrasts, and glacial processes). Lastly, additional factors such as base-level drops should be taken into account for the explanation of knickpoint genesis, especially in the lower Stura valley. 


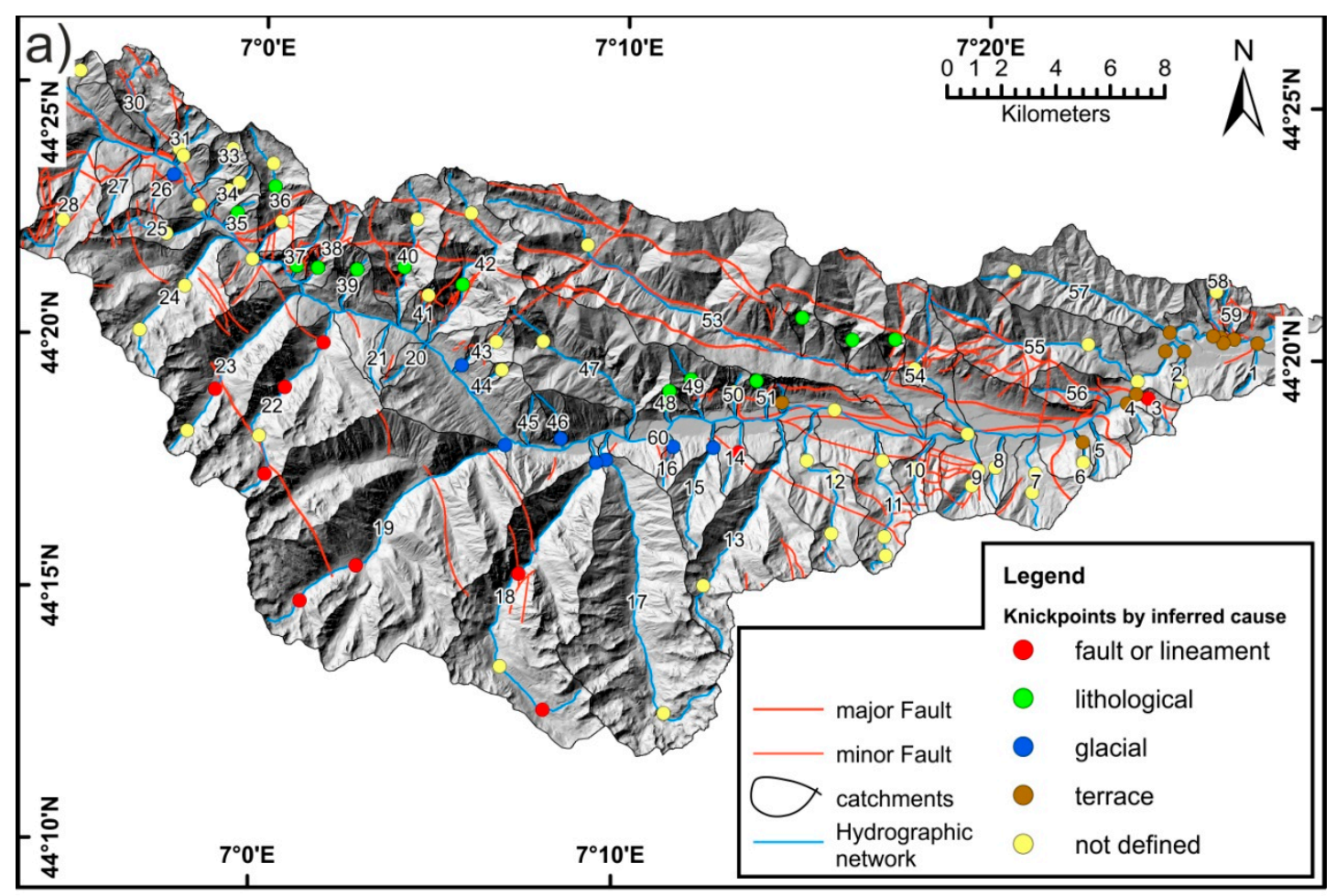

b)

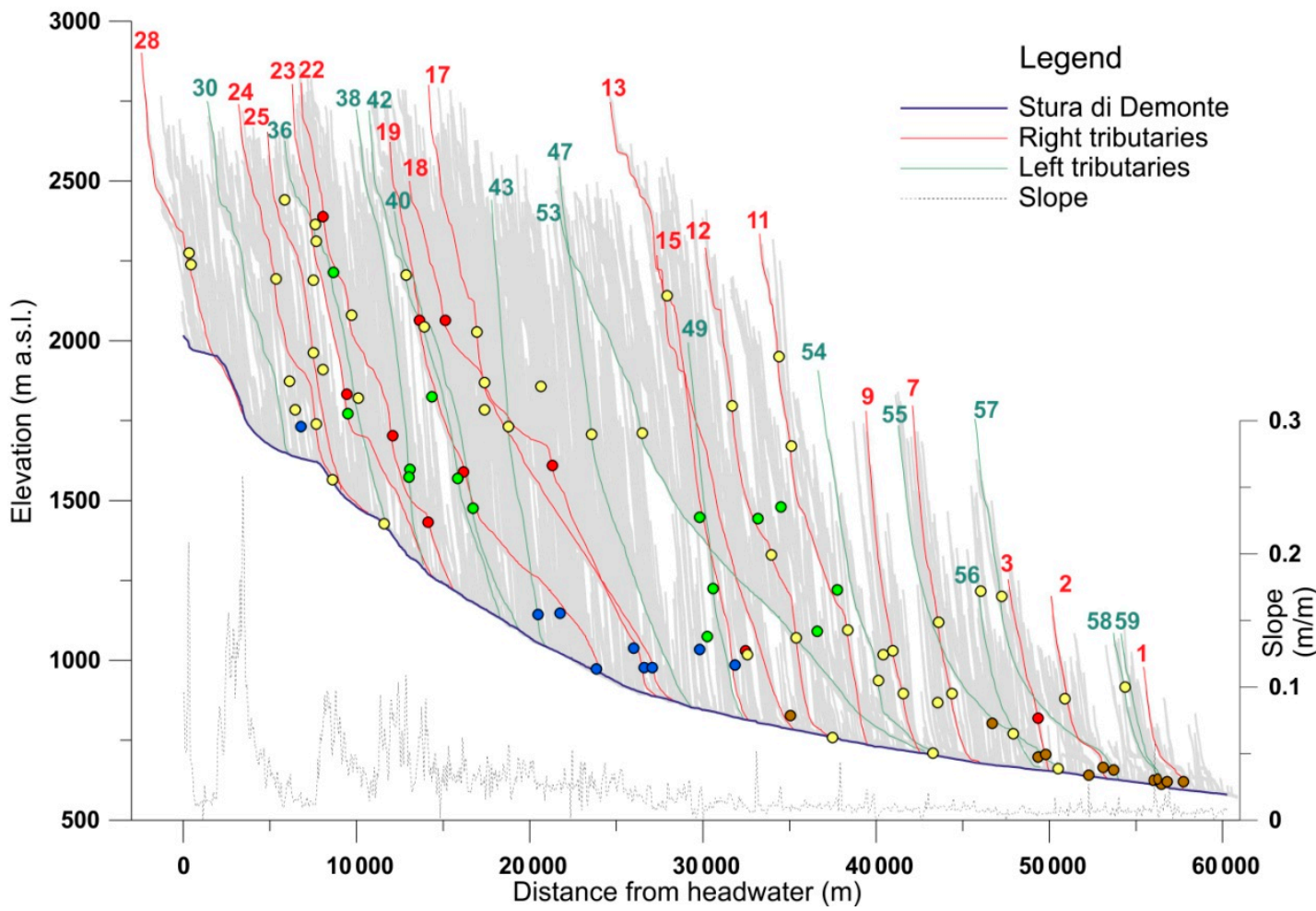

Figure 3. (a) Location of knickpoints in the Stura Valley categorized by their inferred cause; (b) Longitudinal profiles of the Stura di Demonte river and major tributaries. The solid gray lines represent all channel length profiles in the catchment area. (DEM for hillshade from $[57,58]$ ). 


\subsection{Knickpoints Related to Faults}

The main tectonic lineament in the portion of basement incised by the Stura valley is the striking NW-SE Bersezio-Colle della Lombarda fault, a high-angle shear zone, composed by micaschists and mylonitic rocks $[29,34,35,37,64,65]$. Associated with the main system is a dense set of minor faults, which causes relief and strongly drive the gravitational and erosional processes [30].

To evaluate the influence of the tectonic on the crystalline basement of Argentera, we exclusively analyzed the longitudinal profiles of the Stura di Demonte tributaries draining the Massif.

The NW-SE trending faults belonging to the Bersezio-Colle della Lombarda system intersect several important rivers at high angles, so as to provide an ideal geometry for investigating the effects of recent tectonic activity on the rivers.

The longitudinal profiles of several streams (Figure 4) that drain this area of the Stura basin show convex reaches. The spikes on the slope line highlight the abrupt gradient changes along the channels. A clear correlation between stream gradient changes and tectonic structures in the Argentera Massif is evident by the location of knickpoints along the major fault zones. This exact match of knickpoints and faults suggests an adjustment of the river profile to basement blocks characterized by different vertical displacements.
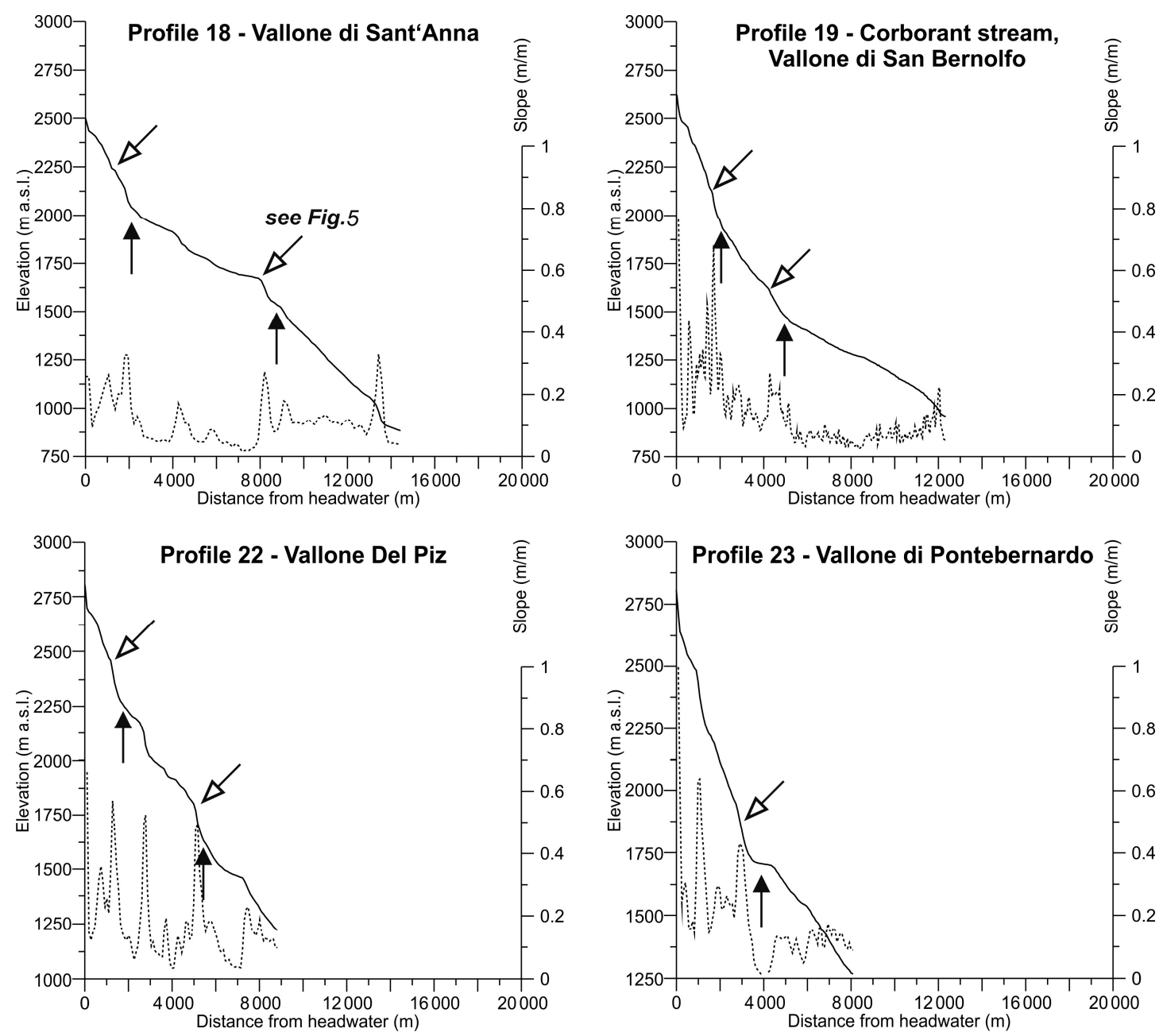

Figure 4. Longitudinal profiles of several streams that drain the Argentera Massif. The vertical black arrows indicate the position of the lineaments, the oblique white arrows point out the position of the knickpoints. The knickpoints are offset up to approx. $200 \mathrm{~m}$ in an upstream direction of the lineaments, indicating the width of a rheological weaker zone caused by the deformation. The spikes in the Slope line are in good agreement with the location of knickpoints. 
One further aspect we have to take into account is the lower rock strength along the fault zone. This could lead to (1) an accentuated knickpoint or (2) increase in the abrasion power of glacial erosion. It is well known that glacial erosion tends to enhance the irregularities in the longitudinal profiles of the valleys creating glacial steps, usually in correspondence to changes in rock properties or fractures, which offer differential resistance to the ice flow [66,67].

The knickpoints that we identified along the faults are the result of differential vertical displacement along faults or of the reduction of rock strength in the fault zones, offering low resistance, for example, to glacial erosion. In the latter case the knickpoints would be indirectly the result of the existence of the faults, but their presence would be directly linked to the glacial abrasion.

One of the main valleys draining the Argentera Massif, e.g., the Vallone di Sant'Anna, is showing clear evidence of lineaments crossing the basin, which cause the uppermost knickpoints along the longitudinal profile (Figure 5).

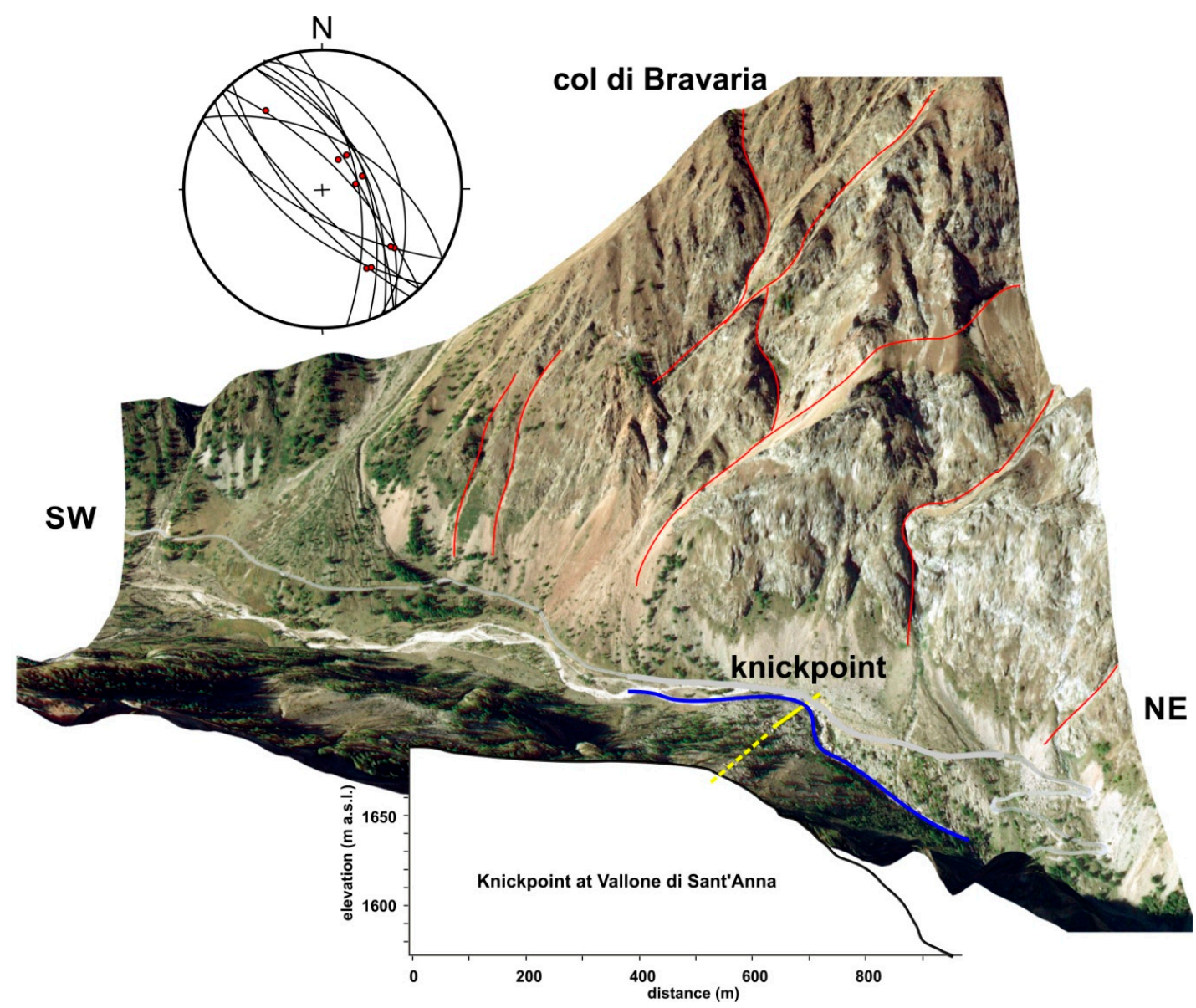

Figure 5. Prevalent tectonic control in the formation of knickpoints in the Vallone di S. Anna. The fault planes in red belong to the NW-SE trending Bersezio-Colle della Lombarda fault system, a Variscan shear zone reactivated during the Alpine tectonic (Schmidt net, lower hemisphere representation of faults and striation measured at the col di Bravaria). The knickpoint is highlighted in yellow, the river in blue, and the street in grey, and is characterized by the change in slope that can be seen in the river length profile. (Image source: Esri World imagery, credits to Source: Esri, DigitalGlobe, GeoEye, i-cubed, USDA, USGS, AEX, Getmapping, Aerogrid, IGN, IGP, swisstopo, and the GIS User Community).

\subsection{Knickpoints Related to Lithological Contrasts}

Since the lithology in the Argentera Massif is considered uniform, the influence of variability in rock resistance has been excluded as knickpoint formation factor. Weaker rock strength along fault 
zones is not considered a cause of knickpoints related to lithological contrasts and is to be attributed to fault-related knickpoints.

In the sedimentary cover outcropping on the northern side of the Stura basin, the different geological formations react differently to weathering and to fluvial erosion, leading to the development of knickpoints or knickzones. Lithology can explain some of the slope variations in those tributaries that flow on the sedimentary cover of the Stura Valley, especially in the upper river tributaries. We recognized a clear lithological influence on the longitudinal profiles of the streams in two regions.

The first area is located in the upper valley, on the northern flank of the basin (Figure 6) developed on the Mesozoic and Cenozoic series of the autochthonous sedimentary cover of the Argentera Massif. These sequences are mainly composed of locally or extensively dolomitized limestone with variable amounts of arenaceous material.

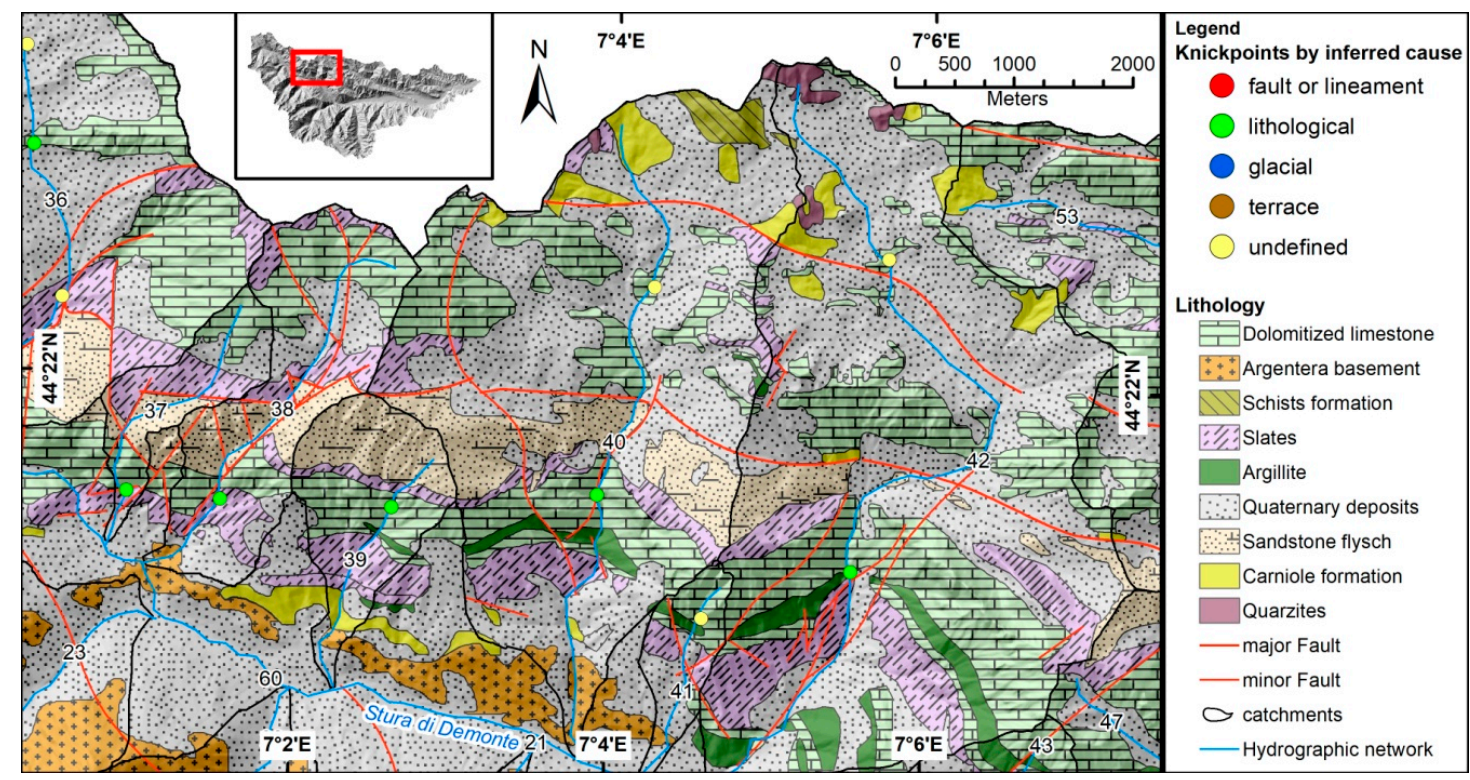

Figure 6. In the southern side of the high-medium valley, the knickpoints are frequently located along the limestone formation, which offers a greater resistance to erosion with respect to the adjacent lithologies (Geology: redrawn and summarized after [35]; DEM for hillshade from [58,59].

The outcrops with limestone and dolomitic rock-types present a greater resistance to erosion compared to the overlying sandstone flysch and slate formation, giving rise to a spectacular cliff in this area of the basin (Figure 7). The elongation axis of the tributary basins crossing the cliff developed in a NNW-SSE direction, while the lithological contact is oriented according to a main direction of 110-120 N The streams cross the lithological contacts almost perpendicularly and the knickpoints are aligned along the limestone-dolomitic outcrop (Figure 6).

The second area, where a strong lithological control is eminent, resides on the northern flank of Vallone dell'Arma, the major tributary basin of the Stura di Demonte. The considered tributary streams flow into the Cant River after crossing the same lithological contacts. The northern flank of the Vallone dell'Arma developed in the Mesozoic sequence of the Briançonnaise zone. The Briançonnaise quartzose schists in the upper portion of the NNE flank are thrusted onto the Giurassic limestone, which forms the external part of a reversed SW-vergent anticline. The NNE flank cuts the top portion of the anticline incising the quarzites at the anticline hinge [34] The knickpoints in this portion of the valley develop frequently on this lithotype (Figure 8). As in the former example, the lithologic contacts follow the direction of the main tectonic lineaments $(110 \mathrm{~N})$, while the northern tributaries of the Cant River flow from NNW to SSE crossing the contacts almost perpendicularly (Figure 8). 


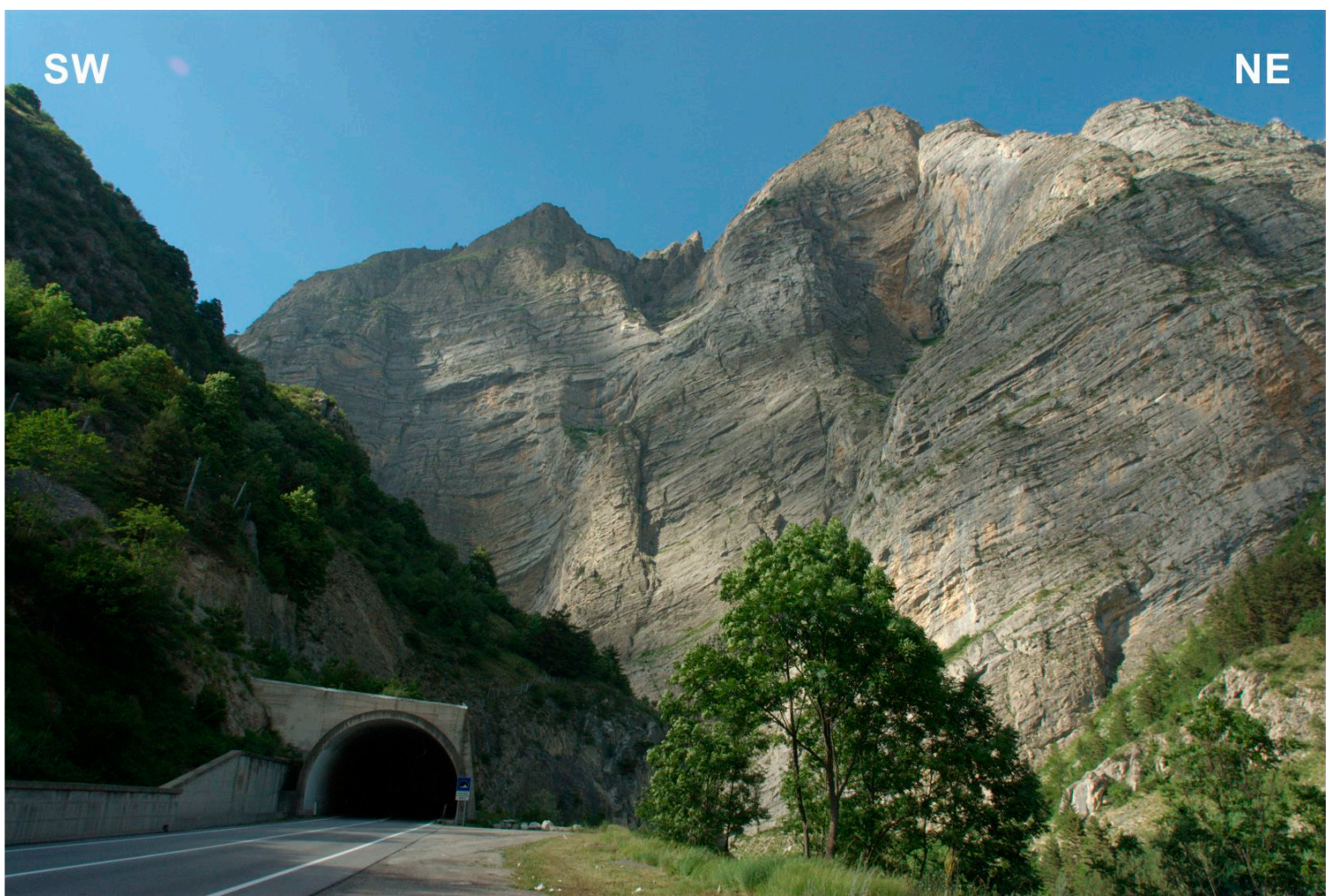

Figure 7. The high cliff called "Le Barricate" more than $200 \mathrm{~m}$ modelled in the limestone formation (Photo: P. Kollerer and M. Isenberg).

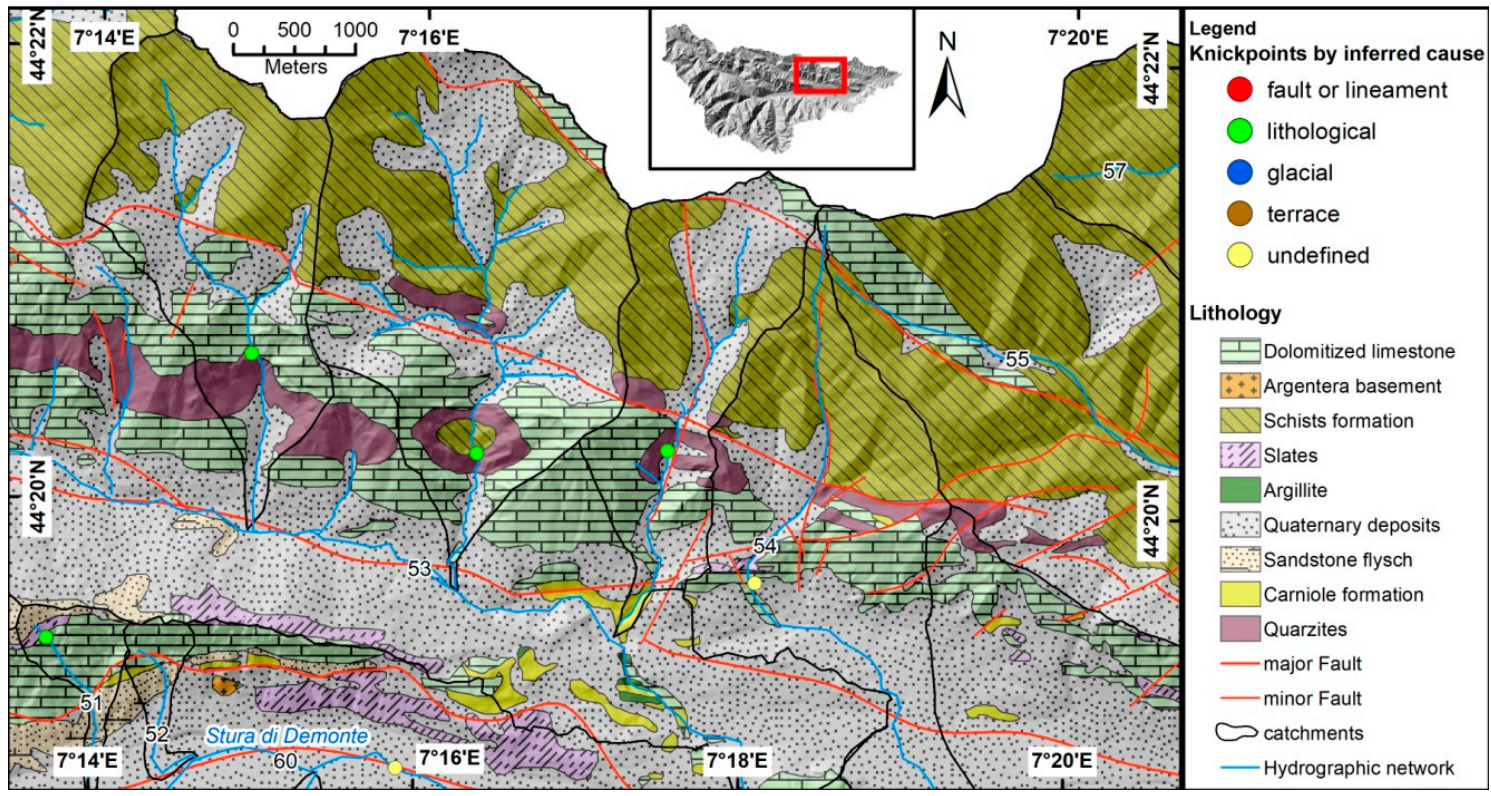

Figure 8. The knickpoints in the low-medium Stura valley are mainly developed on the quarzites (Geology: redrawn and summarized after [35]; DEM for hillshade in Italy from [57,58].

\subsection{Knickpoints Related to Base-Level Change}

In the lower Stura valley knickpoints were recognized in the main channel and in the several tributaries of Stura di Demonte (Figure 9). 


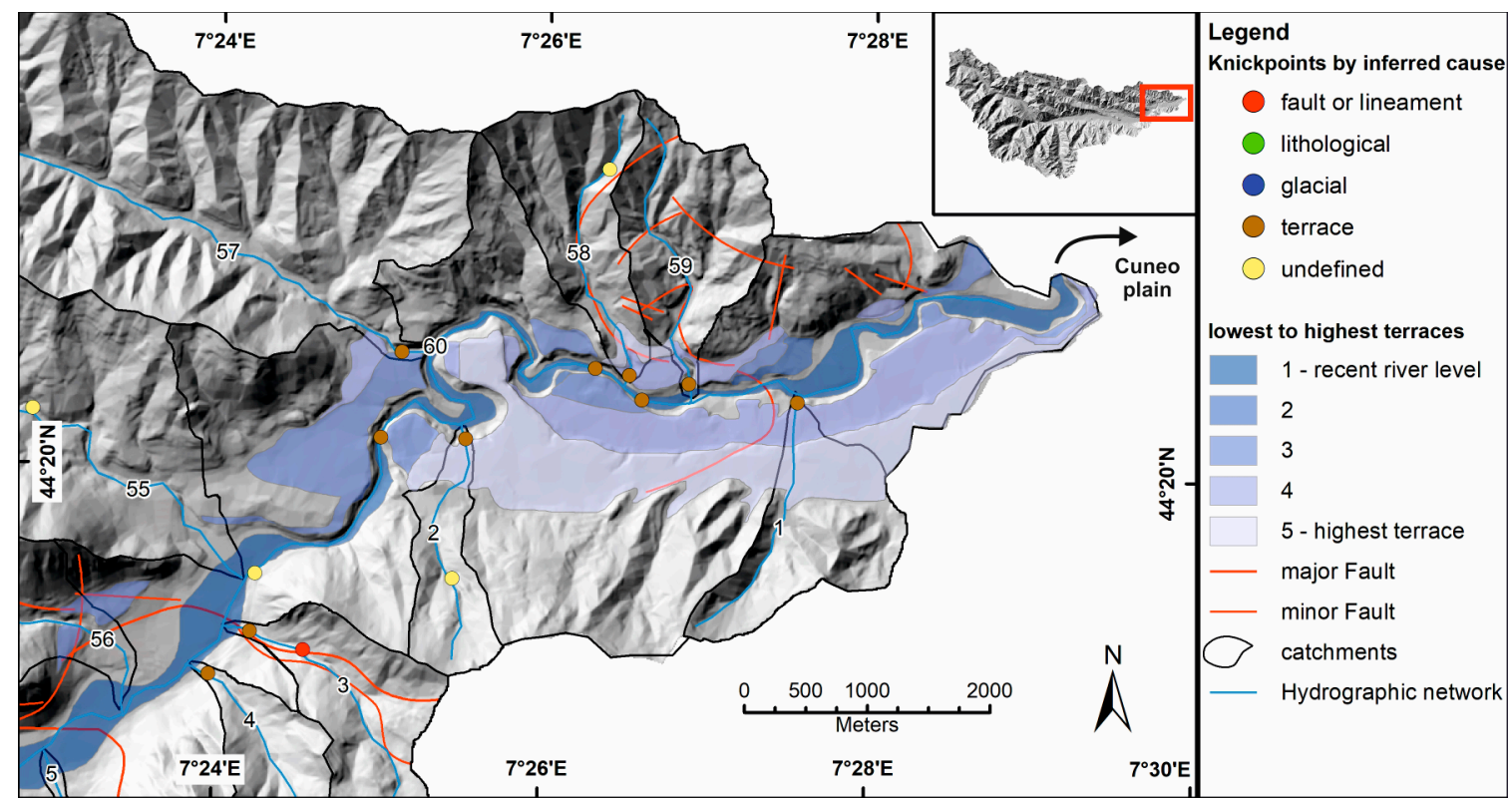

Figure 9. The lower Stura Valley, just before the transition to the Cuneo plain, is marked by up to 5 terrace levels. The Stura di Demonte tributaries form knickpoints when crossing the edge of the terraces (DEM for hillshade from [57,58]; faults from [34].

The lower Stura valley is characterized by five levels of fluvial terraces. We interpret the lower ones as possibly related to base-level drop and to the subsequent regressive erosion caused after Tanaro river deviation. The hypothesis is based on (i) their divergent trends, typical in the backward erosion controlled by local base-level variations [68], and (ii) because the initiation of the backward erosion occurs after the capture of the Tanaro River [26], which took place during or shortly after the last glacial period $[48,49,69]$.

In the low Stura di Demonte valley the knickpoints located in the small tributary basins are coincident or only a little up-stream of the escarpment of fluvial terraces formed by incision in the main valley. In the larger tributary catchments, especially on the northern flank of the Stura basin, these knickpoints are located further upward (Figure 9). Assuming that these knickpoints have a similar genesis, the rate of their upstream migration is modulated by the size of the catchment, as several field and experimental studies have emphasized [4,13,20,70-72].This relation is reflected by the "stream power law", which links river incision and stream power, where stream power relates to discharge $[8,17,73-77]$. However, discharge data are lacking for the tributary basins and this hypothesis, although feasible, should be tested.

Another important factor affecting the spatial location of knickpoints within the river profile is the time necessary for the basin for its readjustment. By assuming an upstream knickpoint migration, the tributaries joining the trunk river further downstream have more time to readjust their profiles than the tributaries up-valley. The longitudinal profiles from small tributary basins show knickpoints closer to their confluence in the trunk stream than the larger ones (Figure 10).

Since the number of basins taken into account is low and the lithology on which they are developed is various, a clear linear relation between knickpoint positions in the basin was not evidenced, but the propagation of knickpoints correlates to the stream power. In the right tributary basins, the stream power is low; in fact, the basins have a seasonal discharge because of their limited areal dimensions and a restricted potential to readjust their longitudinal profiles. Conversely, the northern tributary basins have higher stream power and higher discharge. Figures 1,2 and 9 allow the catchment size differences to be appreciated between right and left tributaries of the lower Stura valley. 

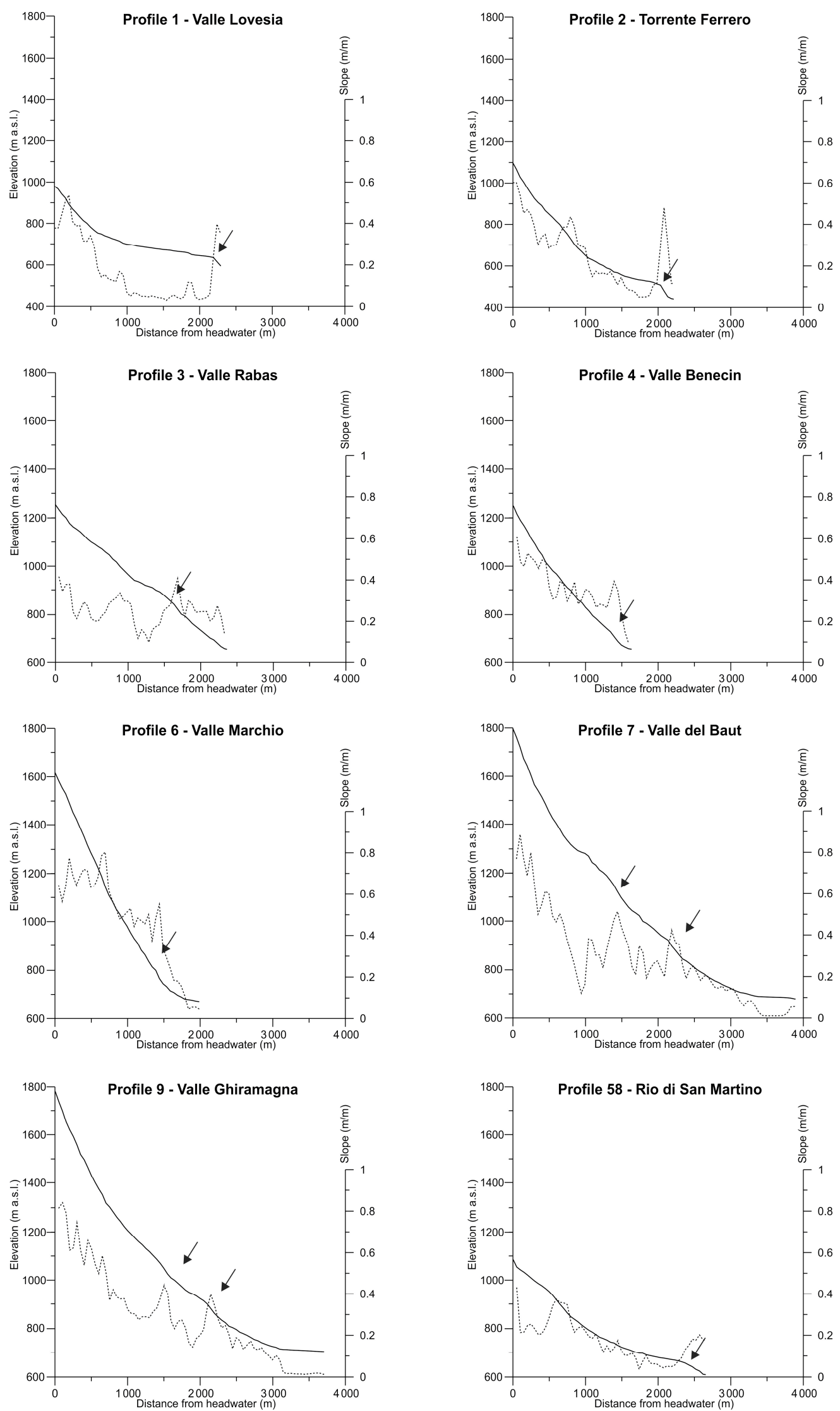

Figure 10. Longitudinal profiles with knickpoints in the tributaries of the lower Stura di Demonte river caused by the terrace levels. 


\subsection{Knickpoints Related to Glacial Residual Morphologies}

The Stura valley, as the other catchments draining the Italian side of the Maritime Alps, was ice-covered during the last glacial period $[52,54,55]$. Numerous landforms such as valley steps and hanging valleys clearly testify the major imprint of glacial erosion on the present-day morphology (Figure 11).
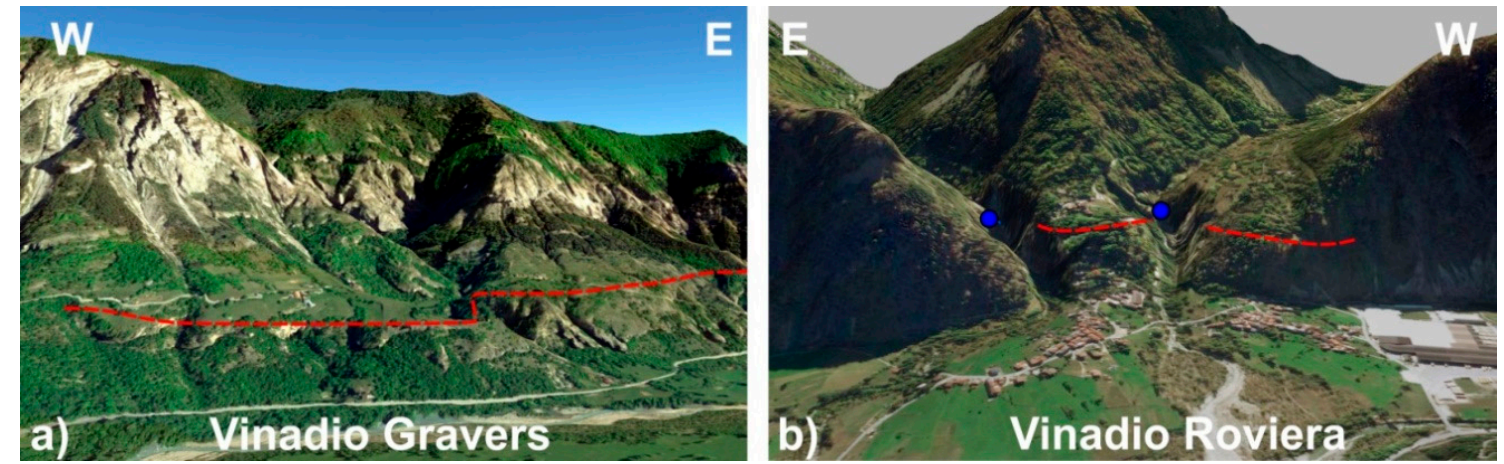

Figure 11. Two tributaries of the Stura valley in the areas of Vinadio gravers (a) and Vinadio Roviera (b). Glacial escarpment (red-dotted line) and the different levels between the lateral valleys and the Stura alluvial plain. Sources: Google Earth (left), Bing Maps, World Wide Telescope (right).

The Stura valley cross-profile shows an accentuated U-shape, typical of a glacial valley, while the two steep sides of the valley indicate the different levels of glacial scarps. Although they are discontinuous and in part badly developed, they can be used as a level for glacier high stand. As the glaciers retreated, many tributary valleys of the Stura di Demonte river formed hanging valleys close to the main river trunk, where glacial erosion was focused. After deglaciation, the base-level of the main valley was well below the level of the Stura di Demonte tributaries. This morphology is still evident in the tributaries in the medium and high parts of the valley where glacial erosion was stronger.

Several tributaries of the Stura di Demonte river still reflect these relict glacial steps near their confluence with the trunk stream. The tributary valleys often show the existence of gorges close to the confluence with the main river, where erosion is enhanced by fluvial processes readjusting the longitudinal profiles. Indeed, recent studies have pointed out that river segments readjusting to glacial overprints have a strong increase in erosion rates [78-80]. The longitudinal profiles of these tributaries are all convex in their downstream segments and have knickpoints formed as steep reaches that connect the tributary valleys to the main trunk (Figure 12). 

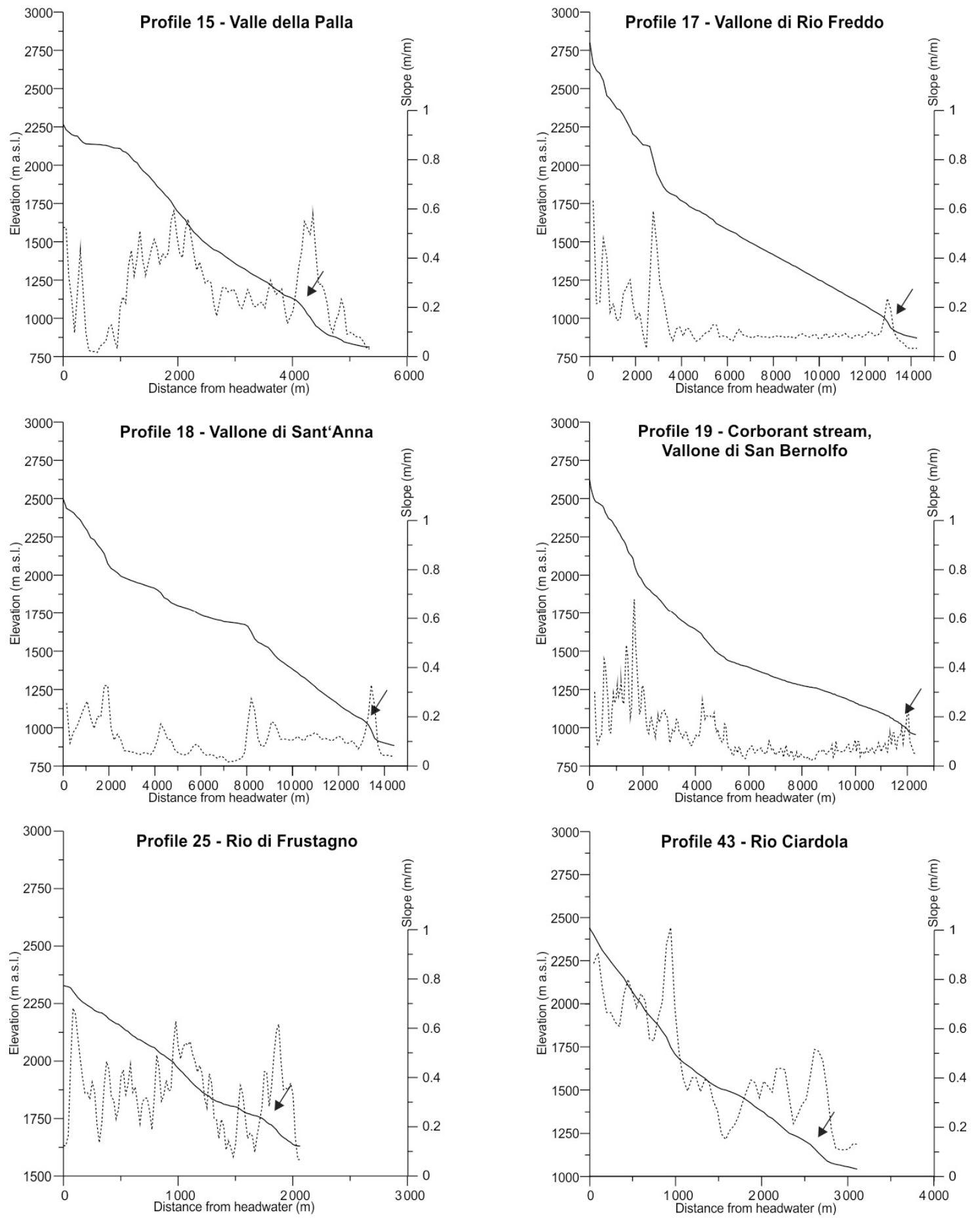

Figure 12. Longitudinal profiles of several streams in the medium Stura valley. All these profiles show a knickpoint in their terminal reaches, in correspondence of relict glacial steps.

\subsection{X-Analysis}

Distributions of knickpoints in X-space are multimodal (Figure 13) thus suggesting that a common causative process of most knickpoints is unlikely. However, peaks in the distributions of knickpoints attributed to glacial landforms and fluvial terraces are quite pronounced and found at low $\mathrm{X}$-values thus close to the main trunk river. The several minor peaks distribution is an expected pattern for knickpoints related to lithological changes and faults. 
Interestingly, the distribution of the knickpoints not-defined in origin (nn in Figure 13) shows two peaks, opening to the possibility that at least one could be related to a common base-level fall.
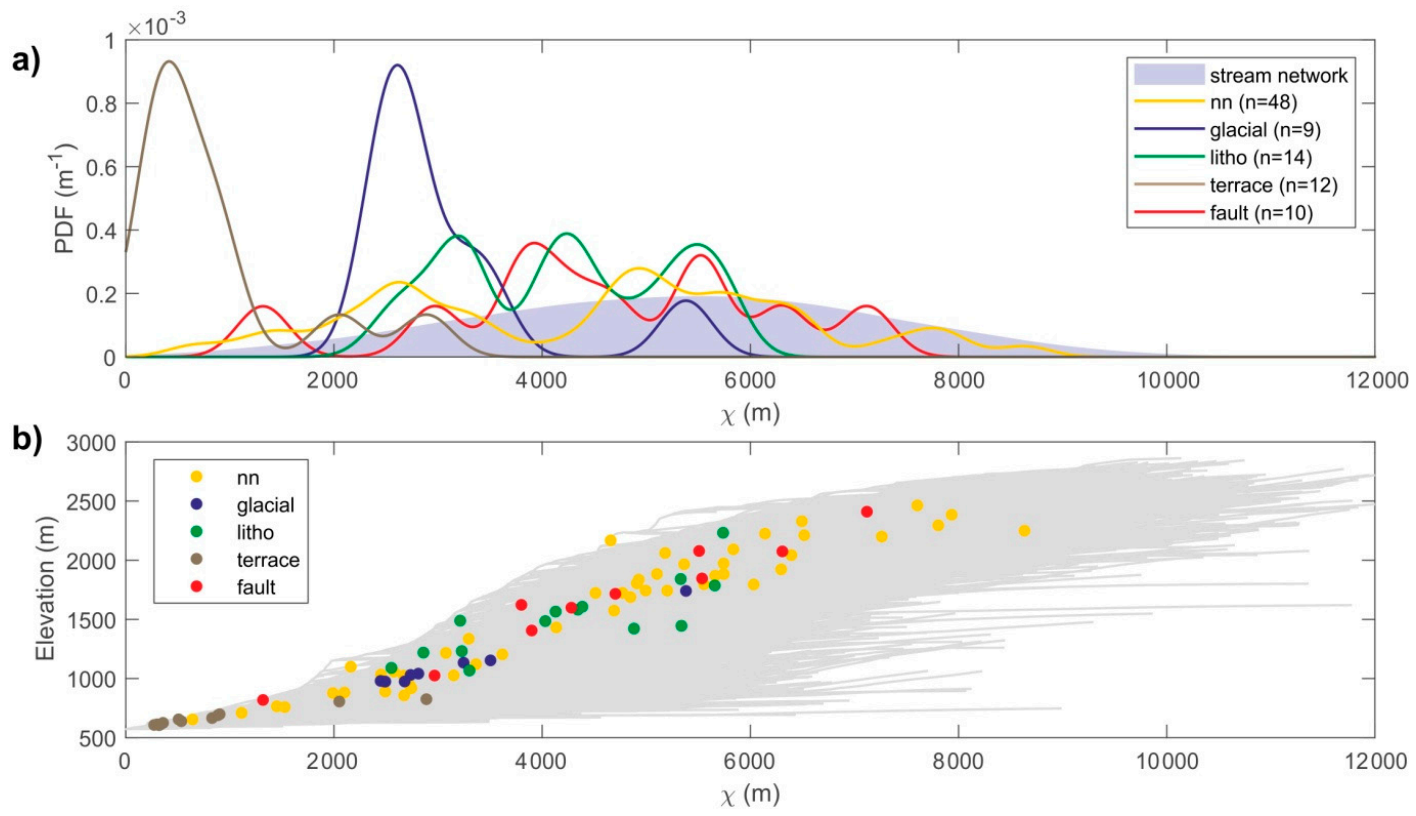

Figure 13. X-analysis of knickpoint locations in the Stura Valley. (a) X-plot of knickpoint locations. (b) Distribution of knickpoints estimated by a kernel density estimator (bandwidth $=250 \mathrm{~m}$ ) in X-space. Knickpoints are categorized by their inferred cause. The blue area is the probability density function (PDF) of the total stream network in the Stura Valley.

\section{Discussion and Conclusions}

The Stura valley shows a complex drainage system that has been influenced by numerous factors during its evolution. A variety of knickpoints are present both in the trunk stream and in its tributaries.

Different local controls act in the basin affecting the fluvial evolution. We grouped the identified knickpoints in categories on the basis of the sole or prevalent process responsible for their origin.

Several knickpoints are in correspondence of the main faults and fault zones that cross the Massif, suggesting a relation between tectonic activity and drainage evolution. However, the resulting knickpoints can be enhanced by the glacial erosion of weak fault rocks. Lithology is considered one of the most important factors affecting the longitudinal profiles of the streams, especially in the sedimentary cover where many different lithotypes are present. Rock types less prone to weathering (limestone or quarzites) in the Stura valley led to perturbed gradients of the streams crossing these units.

We cannot ignore the geomorphological or geological events occurring in the surrounding areas that can affect the evolution of the drainage network of the studied basin. The Tanaro river capture taking place in the Piedmont basin during the Pleistocene affected the evolution of the drainage network in the alpine part of the Stura valley. The Stura river, being the main tributary of the Tanaro, should have been indirectly affected by these geological events that led to a general reorganization of the entire south-west Piedmont drainage network. We believe that some of the knickpoints observed in the tributaries flowing in the lower Stura valley may be linked with the Tanaro deviation, which caused a drop in the base-level recorded on the main valley by the development of several levels of fluvial terraces.

We also observed other river profile irregularities in correspondence of important glacial landforms. LGM glaciation had, indeed, a key role in modeling the morphology of the Stura basin, and we can still observe certain valleys still hanging on the main alluvial plain. 
Some of the identified knickpoints could not be categorized in the above-mentioned groups. More than one single factor may have played a role in the origin of these knickpoints, while other ones could be related to factors that have not been considered herein, for example tributary effects, mass movements, or fluvial captures occurring within the Stura di Demonte basin.

Although the limited number of knickpoints calls for caution in interpretation, a multimodal distribution of knickpoints in the $\mathrm{X}$-space (X-(X)-analysis) confirms that a common causative process is unlikely.

While some authors have explored the relation between knickpoints and some specific factors such as lithology or tectonics, in this work we highlighted the ways in which we can find a variety of genetically different knickpoints, even in a relatively small basin. Drainage networks are frequently very complex environments and their evolution can be influenced by several independent or inter-related factors. In this respect, the Stura valley has resulted in being a suitable environment for studying the sensibility of longitudinal profiles of streams to perturbing factors. We identified several situations where a single local factor has controlled, more than others, the evolution of fluvial reaches. This methodology, based on the identification of knickpoints and on the comparison of their location with geological and geomorphological parameters, entails a wide knowledge of the study area and of its recent evolutionary history.

The identification and analysis of the Stura valley knickpoints allowed the recognition of both regional scale phenomena such as recent tectonic activities or climatic changes as well as local controls such as lithology or fluvial captures.

Although the knickpoints in some environments might be the signal of a general incision pulse as stated by Crosby and Whipple [13], the effect of different local controls should not be overlooked, especially in the investigation of basins with multifarious processes affecting their evolution. As recently stated by Phillips et al. [16] for the Big South Fork River basin (USA), this analysis confirms that, although knickpoints can provide important information on incision signals affecting the networks-especially for large scale analysis-local controls can play an important role in their genesis and development, and should be taken into account in the study of fluvially dissected landscapes.

Author Contributions: Conceptualization, M.M., G.Z., and A.R.; methodology, M.M., G.Z., W.S., and A.R.; software, M.M. and G.Z.; validation, M.M. and A.R.; formal analysis, M.M., G.Z.; W.S., and A.R.; investigation, M.M., G.Z. and A.R.; data curation, M.M.; writing—original draft preparation, M.M.; writing—review and editing, M.M., G.Z., W.S., and A.R.

Funding: "Ateneo" funds (Leader A. Ribolini) for this research were provided by the Department of Earth Sciences of the University of Pisa.

Acknowledgments: We are in debt to P.R Federici who promoted this research and provided insightful comments. The authors would like to thank P. Kollerer and M. Isenberg for field photographs and for additional knickpoints documentation. L. Cignoni improved the English language.

Conflicts of Interest: The authors declare no conflict of interest.

\section{References}

1. Burbank, D.W.; Anderson, R.S. Tectonic Geomorphology; Blackwell Scientific: Oxford, UK, 2001; 270p.

2. Duvall, A.; Kirby, E.; Burbank, D. Tectonic and lithologic controls on bedrock channel profiles and processes in coastal California. J. Geophys. Res. 2004, 109, F03002. [CrossRef]

3. Pearce, S.A.; Pazzaglia, F.J.; Eppes, M.C. Ephemeral stream response to growing folds. Geol. Soc. Am. Bull. 2004, 116, 1223-1239. [CrossRef]

4. Bishop, P.; Hoey, T.B.; Jansen, J.D.; Artza, I.L. Knickpoint recession rate and catchment area: The case of uplifted rivers in Eastern Scotland. Earth Surf. Proc. Land. 2005, 30, 767-778. [CrossRef]

5. Carretier, S.; Nivière, B.; Giamboni, M.; Winter, T. Do river profiles record alongstream variations of low uplift rate? J. Geophys. Res. 2006, 111, 1-16. [CrossRef]

6. Mackin, J.H. Concept of the graded river. Geol. Soc. Am. Bull. 1948, 59, 463-512. [CrossRef] 
7. Hack, J.T. Studies of Longitudinal Stream Profiles in Virginia and Maryland; US Government Printing Office: Washington, DC, USA, 1957; Volume 294, pp. 45-97.

8. Howard, A.D.; Dietrich, W.E.; Seidl, M.A. Modeling fluvial erosion on regional to continental scales. J. Geophys. Res. 1994, 99, 13971-13986. [CrossRef]

9. Whipple, K.X.; Tucker, G.E. Dynamics of the Stream Power River Incision Model: Implications for Height Limits of Mountain Ranges, Landscape Response Timescales and Research Needs. J. Geophys. Res. 1999, 104, 17661-17674. [CrossRef]

10. Richard, K.S. Rivers: Form and Process in Alluvial Channels; Methuen: London, UK, 1982; 358p.

11. Knighton, A.D. Fluvial Forms and Processes: A New Perspective; Arnold: London, UK, 1998; 383p.

12. Schumm, S.A. River Variability and Complexity; Cambridge University Press: New York, NY, USA, 2005; 200p.

13. Crosby, B.T.; Whipple, K.X. Knickpoint initiation and distribution within fluvial networks: 236 waterfalls in the Waipaoa River, North Island, New Zealand. Geomorphology 2006, 82, 16-38. [CrossRef]

14. Larue, J.P. Effects of tectonics and lithology on long profiles of 16 rivers of the southern Central Massif border between the Aude and the Orb (France). Geomorphology 2008, 93, 343-367. [CrossRef]

15. Phillips, J.D.; Lutz, J.D. Profile convexities in bedrock and alluvial streams. Geomorphology 2008, 102, 554-566. [CrossRef]

16. Phillips, J.D.; McCormack, S.; Duan, J.; Russo, J.P.; Schumacher, A.M.; Tripathi, G.N.; Brockman, R.B.; Mays, A.B.; Pulugurtha, S. Origin and interpretation of knickpoints in the Big South Fork River basin, Kentucky-Tennessee. Geomorphology 2010, 114, 188-198. [CrossRef]

17. Royden, L.; Perron, J.T. Solutions of the stream power equation and application to the evolution of river longitudinal profiles. J. Geophys. Res. 2013, 118, 1-22. [CrossRef]

18. DiBiase, R.A.; Whipple, K.X.; Lamb, M.P.; Heimsath, A.M. The role of waterfalls and knickzones in controlling the style and pace of landscape adjustment in the western San Gabriel Mountains, California. Geol. Soc. Am. Bull. 2015, 127, 539-559. [CrossRef]

19. Abbott, L.D.; Lundstrom, C.; Traub, C. Rates of river incision and scarp retreat in eastern and central Grand Canyon over the past half million years: Evidence for passage of a transient knickzone. Geosphere 2015, 11, 638-659. [CrossRef]

20. Grimaud, J.L.; Paola, C.; Voller, V. Experimental migration of knickpoints: Influence of style of base-level fall and bed lithology. Earth Surf. Dyn. 2016, 4, 11-23. [CrossRef]

21. Neely, A.B.; Bookhagen, B.; Burbank, D.W. An automated knickzone selection algorithm (KZ-Picker) to analyze transient landscapes: Calibration and validation. J. Geophys. Res.: Earth Surf. 2017, 122, 1236-1261. [CrossRef]

22. Casarosa, N. Evoluzione Geomorfologica dell'Alta Valle Stura (Alpi Marittime). Master Thesis, University of Pisa, Pisa, Italy, 2001.

23. Capitani, M. Evoluzione Geomorfologica Recente Della Media e Bassa Valle Stura (Alpi Marittime). Master Thesis, University of Pisa, Pisa, Italy, 2002.

24. Spagnolo, M. The asymmetry of the middle and lower portions of the Vallone dell'Arma, Stura Valley (Maritime Alps). Atti Fisici 2005, 139, 3-16.

25. Spagnolo, M. Illustrative notes of the Geomorphological Map of the Upper Arma Valley (Stura di Demonte Valley, Maritime Alps). Geogr. Fis. Dinam. Quat. 2007, 30, 117-125.

26. Capitani, M.; Marrucci, M. The Demonte Terrace in the Stura Valley (Maritime Alps) between climatic changes and tectonic movements. Geogr. Fis. Dinam. Quat. 2008, 31, 5-12.

27. Ribolini, A. Il ruolo morfostrutturale e morfoselettivo delle rocce milonitiche nella parte sud-orientale del Massiccio Cristallino dell'Argentera (Alpi Marittime). Boll. Soc. Geol. Ital. 1999, 117, 657-677.

28. Ribolini, A. Relief distribution, morphology and Cenozoic differential uplift in the Argentera Massif (French-Italian Alps). Z. Geomorphol. 2000, 44, 363-378.

29. Musumeci, G.; Ribolini, A.; Spagnolo, M. The effect of late Alpine tectonics in the morphology of the Argentera Massif (Western Alps, Italy-France). Quat. Int. 2003, 101, 191-201. [CrossRef]

30. Ribolini, A.; Spagnolo, M. Drainage network geometry versus tectonics in the Argentera Massif (French-Italian Alps). Geomorphology 2008, 93, 253-266. [CrossRef] 
31. Saillard, M.; Petit, C.; Rolland, Y.; Braucher, R.; Bourlès, D.L.; Zerathe, S.; Revel, M.; Jourdon, A. Late Quaternary incision rates in the Vésubie catchment area (Southern French Alps) from in situ-produced 36Cl cosmogenic nuclide dating: Tectonic and climatic implications. J. Geophys. Res. Earth Surf. 2014, 119, 1121-1135. [CrossRef]

32. Rolland, Y.; Petit, C.; Saillard, M.; Braucher, R.; Bourlès, D.; Darnault, R.; Cassol, D. Inner gorges incision history: A proxy for deglaciation? Insights from Cosmic Ray Exposure dating (10Be and $36 \mathrm{Cl}$ ) of river-polished surfaces (Tinée River, SW Alps, France). Earth Planet. Sci. Lett. 2016, 457, 271-281. [CrossRef]

33. Petit, C.; Goren, L.; Rolland, Y.; Bourlès, D.; Braucher, R.; Saillard, M.; Cassol, D. Recent, climate-driven river incision rate fluctuations in the Mercantour crystalline massif, southern French Alps. Quat. Sci. Rev. 2017, 165, 73-87. [CrossRef]

34. Malaroda, R.; Carraro, F. Carta Geologica del Massiccio dell'Argentera alla scala 1:50.000 e note illustrative. Mem. Soc. Geol. Ital. 1970, 9, 557-663.

35. Baietto, A.; Perello, P.; Cadoppi, P.; Martinotti, G. Alpine tectonic evolution and thermal water circulations of the Argentera Massif (South-Western Alps). Swiss J. Geosci. 2009, 102, 223-245. [CrossRef]

36. Bonetto, S.M.R.; Facello, A.; Umili, G. A new application of CurvaTool semi-automatic approach to qualitatively detect geological lineaments. Environ. Eng. Geosci. 2017, 23, 179-190. [CrossRef]

37. Bogdanoff, S. Evolution de la partie occidentale du Massif Cristallin Externe de l'Argentera. Place dans l'arc alpin. Geol. France 1986, 4, 433-453.

38. Horrenberger, J.C.; Michard, A.; Werner, P. Le couloir de décrochement de Bersezio en Haute Stura, Alpes Externe, Italie, Structure de compression subméridienne. Sci. Géol. Bull. 1978, 31, 15-20. [CrossRef]

39. Fry, N. Southwestward thrusting and tectonics of the western Alps. In Alpine Tectonics; Coward, M.P., Dietrich, D., Park, R.G., Eds.; Geological Society London Special Publication: London, UK, 1989; pp. 83-109.

40. Perello, P.; Piana, F. Neogenic thrust and strike-Slip tectonics at the northen boundaty between the Argentera Massif and its metasedimentary cover. Quad. Geodin. Alp. Quat. 1997, 4, 205.

41. Bigot-Cormier, F.; Poupeau, G.; Sosson, M. Dénudations différentielles du massif cristallin externe alpin de l'Argentera (SE de la France) révélées par thermochronologie sur traces de fission (apatites, zircons). C. R. Acad. Sci. Paris 2000, 300, 363-370.

42. Bogdanoff, S.; Michard, A.; Mansour, M.; Poupeau, G. Apatite fission tracks analysis in the Argentera massif: Evidence of contrasting denudation rates in the External Crystalline Massifs of the Western Alps. Terra Nova 2000, 12, 117-125. [CrossRef]

43. Bigot-Cormier, F. La Surrection du Massif Cristallin Externe de l'Argentera (France-Italie) et ses Relations avec la Déformation Pliocène de la Marge Nord-Ligure: Arguments Thermochronologiques (Traces de Fission), Géomorphologiques et Interprétations de Sismique Marine. Ph.D. Thesis, Université de Nice Sophia Antipolis, Nice, France, 2002.

44. Frechet, J.; Pavoni, N. Etude de la sismicité de la zone brianconnaise entre Pelvoux et argentera (Alpes occidentales) à l'aide d'un réseau de stations portables. Eclogae Geol. Helv. 1979, 72, 763-779.

45. Madeddu, B.; Bertoux, N.; Stephan, J.F. Champ de contraine post-pliocene et deformation recentes dans les Alpes sud-occidentales. Bull. Soc. Géol. France 1996, 8, 797-810.

46. Calais, E.; Galisson, L.; Stéphan, J.; Delteil, J.; Deverchère, J.; Larroque, C.; Mercier de Lépinay, B.; Popoff, M.; Sosson, M. Crustal strain in the southern Alps, France, 1948-1998. Tectonophysics 2000, 319, 1-17. [CrossRef]

47. Biancotti, A. L'evoluzione recente ed attuale di un tratto della alta Pianura Padana del Piemonte sud-occidentale. Mem. Acc. Naz. Lincei 1977, 14, 191-225.

48. Biancotti, A. Il quaternario dell'area compresa fra Stura di Demonte e Tanaro (Piemonte sud occidentale). Acc. Naz. Lincei 1979, 3, 1-10.

49. Biancotti, A. Rapporti tra morfologia e tettonica nella Pianura Cuneese. Geograf. Fis. Dinam. Quat. 1979, 2, 51-56.

50. Finsinger, W.; Ribolini, A. Late glacial to Holocene deglaciation of the Colle del Vei del Bouc-Colle del Sabbione Area (Argentera Massif, Maritime Alps, Italy-France). Geograf. Fis. Dinam. Quat. 2001, 24, 141-156.

51. Ribolini, A.; Chelli, A.; Guglielmin, M.; Pappalardo, M. Relationships between glacier and rock glacier in the Maritime Alps, Schiantala Valley, Italy. Quat. Res. 2007, 68, 353-363. [CrossRef]

52. Federici, P.R.; Granger, D.E.; Pappalardo, M.; Ribolini, A.; Spagnolo, M.; Cyr, A.J. Exposure age dating and Equilibrium Line Altitude reconstruction of an Egesen moraine in the Maritime Alps, Italy. Boreas 2008, 37, 245-253. [CrossRef] 
53. Ribolini, A.; Guglielmin, M.; Fabre, D.; Bodin, X.; Marchisio, M.; Sartini, S.; Spagnolo, M.; Schoeneich, P. The internal structure of rock glaciers and recently-deglaciated slopes as revealed by geoelectrical tomography: Insights on permafrost and recent glacial evolution in the Central and Western Alps (Italy-France). Quat. Sci. Rev. 2010, 29, 507-521. [CrossRef]

54. Federici, P.R.; Granger, D.E.; Pappalardo, M.; Ribolini, A.; Spagnolo, M.; Cyr, A.J. Last Glacial Maximum and the Gschnitz stadial in the Maritime Alps according to 10Be cosmogenic dating. Boreas 2011, 41, 277-291. [CrossRef]

55. Federici, P.R.; Ribolini, A.; Spagnolo, M. Glacial history of the Maritime Alps from the Last Glacial Maximum to the Little Ice Age. In Quaternary Glaciation in the Mediterranean Mountains; Hughes, P.D., Woodward, J.C., Eds.; Geological Society Special Publications: London, UK, 2017; pp. 137-159.

56. Stefanini, M.C.; Ribolini, A. Dendrogeomorphological investigations of debrisflow occurrence in the Maritime Alps (northwestern Italy). In Debris-Flow Hazards Mitigation-Mechanics, Prediction, and Assessment; Rickenmann, D., Chen, C., Eds.; Millpress: Rotterdam, The Netherlands, 2003; pp. 231-242.

57. Tarquini, S.; Isola, I.; Favalli, M.; Mazzarini, F.; Bisson, M.; Pareschi, M.T.; Boschi, E. TINITALY/01: A new Triangular Irregular Network of Italy. Ann. Geophys. 2007, 50, 407-425.

58. Tarquini, S.; Vinci, S.; Favalli, M.; Doumaz, F.; Fornaciai, A.; Nannipieri, L. Release of a 10-m-resolution DEM for the Italian territory: Comparison with global-coverage DEMs and anaglyph-mode exploration via the web. Comp. Geosci. 2012, 38, 168-170. [CrossRef]

59. Guglielmetti, L.; Comina, C.; Abdelfettah, Y.; Schill, E.; Mandrone, G. Integration of 3D geological modeling and gravity surveys for geothermal prospection in an Alpine region. Tectonophysics 2013, 608, 1025-1036. [CrossRef]

60. American Society for Testing and Materials. Standard Test Method for Determination of Rock Hardness by Rebound Hammer Method; ASTM International: West Conshohocken, PA, USA, 2001.

61. Lague, D. The stream power river incision model: Evidence, theory and beyond. Earth Surf. Process. Landf. 2014, 39, 38-61. [CrossRef]

62. Perron, J.T.; Royden, L. An integral approach to bedrock river profile analysis. Earth Surf. Process. Landf. 2013, 38, 570-576. [CrossRef]

63. Schwanghart, W.; Scherler, D. TopoToolbox 2-MATLAB-based software for topographic analysis and modeling in Earth surface sciences. Earth Surf. Dynam. 2014, 2, 1-7. [CrossRef]

64. Malaroda, R. Prime osservazioni sulla tettonica ed il metamorfismo in corrispondenza del prolungamento sud-orientale della sinclinale intracristallina Lago del Vei del Bouc-Colle del Sabbione (Argentera Meridionale). Mem. Soc. Geol. Ital. 1974, 9, 557-663.

65. Bogdanoff, S.; Menot, R.P.; Vivier, G. Les Massifs Cristallins Externes des Alpes Occidentales francaises, un fragment de la zone interne varisque. Sci. Geol. Bull. 1991, 44, 237-285. [CrossRef]

66. Morland, L.W.; Morris, E.M. Stress in an elastic bedrock hump due to glacier flow. J. Glaciol. 1977, 18, 67-75. [CrossRef]

67. Bennett, M.R.; Glasser, N.F. Glacial Geology: Ice Sheets and Landforms, 2nd ed.; Wiley-Blackwell: Chichester, UK, 2009; p. 385.

68. Bull, W.N. Geomorphic Responses to Climate Change; Oxford University Press: New York, NY, USA, 1991.

69. Gabert, P. Les plaines Occidentales du Po et leurs Piedmonts (Piemont, Lombardie Occidentale et Centrale). In Etude Geomorphologique; Imprimerie Louis-Jean: Paris, France, 1962; p. 531.

70. Schumm, S.A.; Mosley, M.P.; Weaver, W.E. Experimental Fluvial Geomorphology; John Wiley and Sons: New York, NY, USA, 1987; p. 413.

71. Parker, R.S. Experimental Study of Basin Evolution and Its Hydrologic Implications. Ph.D. Thesis, Colorado State University, Fort Collins, CO, USA, 1977.

72. Rosenbloom, N.A.; Anderson, R.S. Hillslope and channel evolution in a marine terraced landscape, Santa Cruz, California. J. Geoph. Res. 1994, 99, 14013-14029. [CrossRef]

73. Loget, N.; Davy, P.; Van Den Driessche, J. Mesoscale fluvial erosion parameters deduced from modeling the Mediterranean sea level drop during the Messinian (late Miocene). J. Geophys. Res. 2006, 111, F03005. [CrossRef]

74. Berlin, M.M.; Anderson, R.S. Modeling of knickpoint retreat on the Roan Plateau, western Colorado. J. Geophys. Res. 2007, 112, F03S06. [CrossRef]

75. Howard, A.D.; Kerby, G. Channel changes in badlands. Geol. Soc. Am. Bull. 1983, 94, 739-752. [CrossRef] 
76. Seidl, M.A.; Dietrich, W.E.; Kirchner, J.W. Longitudinal profile development into bedrock: An analysis of Hawaiian channels. J. Geol. 1994, 102, 457-474. [CrossRef]

77. Sklar, L.; Dietrich, W.E. Sediment supply, grain size, and rock strength controls on rates of river incision into bedrock. Geology 2001, 29, 1087-1090. [CrossRef]

78. Norton, K.P.; von Blanckenburg, F.; Kubik, P.W. Cosmogenic nuclide-derived rates of diffusive and episodic erosion in the glacially sculpted upper Rhone Valley, Swiss Alps. Earth. Surf. Proc. Land. 2010, 35, 651-662. [CrossRef]

79. Norton, K.P.; von Blanckenburg, F.; Schlunegger, F.; Schwab, M.; Kubik, P.W. Cosmogenic nuclide-based investigation of spatial erosion and hillslope channel coupling in the transient foreland of the Swiss Alps. Geomorphology 2008, 95, 474-486. [CrossRef]

80. Valla, P.G.; van der Beek, P.A.; Carcaillet, J. Dating bedrock gorge incision in the French Western Alps (Ecrins-Pelvoux massif) using cosmogenic 10Be. Terra Nova 2010, 22, 18-25. [CrossRef]

(C) 2018 by the authors. Licensee MDPI, Basel, Switzerland. This article is an open access article distributed under the terms and conditions of the Creative Commons Attribution (CC BY) license (http:/ / creativecommons.org/licenses/by/4.0/). 